\title{
Analysis of Degradation of Creep Strength in Heat-affected Zone of Weldment of High Cr Heat-resisting Steels Based on Void Observation
}

\author{
Kenji SHINOZAKI, De-Jun LI, ${ }^{1)}$ Hidenori KUROKI, Hidemasa HARADA ${ }^{21}$ and Koji OHISHI ${ }^{2 l}$ \\ Department of Mechanical System Engineering, Graduate School of Engineering, Hiroshima University, $739-8527$ Japan. \\ E-mail: kshino@hiroshima-u.ac.jp 1) Graduate Student of Department of Mechanical System Engineering, Graduate \\ School of Engineering, Hiroshima University, 739-8527 Japan. E-mail: Idjun@hiroshima-u.ac.jp \\ 2) Former Graduate Student of Department of Mechanical System Engineering, Graduate School of Engineering, Hiroshima \\ University.
}

(Received on May 20, 2002; accepted in final form on October 2, 2002)

\begin{abstract}
The deterioration of creep rupture strength in welded joints of high $\mathrm{Cr}$ ferritic heat-resisting steels was investigated based on creep tests of internal pressure specimens and single pass welded specimens. Results showed that at high temperature and low stress cracks occurred in the fine-grained heat-affected zone (FGHAZ) and was identified to be Type IV cracking. It was found that the peak weld temperature between app. $A c_{1}$ and app. $A_{c_{3}}$ led to the Type IV cracking and many creep voids were observed in the FGHAZ. Further, effects of creep time on specimen necking, void distribution and precipitate coarsening were investigated. It was found that the creep void occurrence and specimen diameter reduction increased at an accelerating rate during creep. Precipitate observation showed that after long time precipitate coarsening was more in the FGHAZ than in the base metal (BM) and in the coarse-grained HAZ (CGHAZ). Auger Electron Spectroscopy (AES) point analysis showed that many precipitates existed in creep voids. Based on this observation, it was suggested that large precipitates were preferential sites for void nucleation. Finally, simulations using a welded joint model and a matrix/precipitate model were performed to investigate creep void occurrence. Results showed that creep deterioration easily occurred in the FGHAZ and large precipitates present in this zone acted as nucleation sites for voids.
\end{abstract}

KEY WORDS: heat-resisting steel; ferrite; creep strength; HAZ; Type IV cracking; FEM.

\section{Introduction}

High $\mathrm{Cr}$ ferritic heat-resisting steel is often regarded as the most potential material for ultra-supercritical (USC) fossil-fired power. ASME P122 (11Cr-2W-0.4Mo-CuVNb in $\mathrm{wt} \%)$ and ASME P92 (9Cr-1.8W-0.5Mo-NbV in $\mathrm{wt} \%)$ are typical of these steels and have been used as structural materials for boiler components at $873 \mathrm{~K}$ and $25 \mathrm{MPa}$ due to their good material properties, especially high creep rupture strength, the most important property for high pressure and temperature applications. ${ }^{1-7)}$ Further, these two steels are being tried for applications at higher temperatures.

However, creep crack often occurs in the FGHAZ of welded joints of ASME P122 and ASME P92 at high temperature and low stress. This is known as Type IV cracking and leads to a short creep life of the welded joint compared with the base metal. It is necessary to clarify the mechanism of Type IV cracking but until now the phenomenon is not fully understood..$^{8-12)}$

This paper aims at investigating the cause of occurrence of Type IV cracking. Internal pressure creep tests were carried out to investigate the features of Type IV cracking in pipe components and single pass welded joint creep tests were to investigate the accurate relationship between Type IV cracking and welding thermal cycle. Creep void is an important phenomenon in creep damage ${ }^{13)}$ and the observation of the specimens showed that creep voids played an important role in the degradation of creep property in the FGHAZ and was considered to be a key to describe the characteristics of Type IV cracking. Finally, several factors affecting creep void occurrence were analyzed based on the experiment and simulation respectively.

\section{Materials and Experimental Procedure}

\subsection{Materials}

ASME P122 and ASME P92 are W strengthened high Cr ferritic steels. Chemical compositions of the two steels and filler wires used in this study are listed in Table 1. The base metal of ASME P122 was subjected to normalizing at $1323 \mathrm{~K}$ for $1 \mathrm{~h}$ and tempering at $1033 \mathrm{~K}$ for $1 \mathrm{~h}$. The base metal of ASME P92 was subjected to normalizing at $1338 \mathrm{~K}$ for $2 \mathrm{~h}$ and tempering at $1043 \mathrm{~K}$ for $2 \mathrm{~h}$. Both of them were cooled in air. Typical microstructures of ASME 
Table 1. Chemical compositions of ASME P122 and ASME P92 used (wt $\%$ ).

\begin{tabular}{|c|c|c|c|c|c|c|c|c|c|c|c|c|c|c|c|c|c|c|}
\hline & & & C & $\mathrm{Si}$ & $\mathrm{Mn}$ & $P$ & $S$ & $\mathrm{Cr}$ & $\mathrm{W}$ & $\mathrm{Cu}$ & Mo & $\mathrm{Nb}$ & $\mathrm{V}$ & $\mathrm{N}$ & $\mathrm{Ni}$ & B & $\mathrm{Al}$ & $\mathrm{Fe}$ \\
\hline \multirow{4}{*}{$\begin{array}{l}\text { ASME } \\
\text { P122 }\end{array}$} & \multirow{2}{*}{ BM } & P122-IP & \begin{tabular}{|l|}
0.13 \\
\end{tabular} & 0.33 & 0.62 & 0.012 & 0.001 & 10.34 & 2.21 & 0.50 & 0.35 & 0.05 & 0.22 & 0.055 & 0.31 & 0.0026 & 0.019 & Bal. \\
\hline & & P122-SP & 0.12 & 0.33 & 0.60 & 0.014 & 0.003 & 10.78 & 1.93 & 0.92 & 0.34 & 0.06 & 0.19 & 0.064 & 0.35 & 0.0029 & - & Bal. \\
\hline & \multirow{2}{*}{ FM } & F122-IP & 0.01 & 0.30 & 0.52 & 0.003 & 0.002 & 10.32 & 1.60 & 1.45 & 0.32 & 0.05 & - & 0.05 & 1.08 & - & - & Bal. \\
\hline & & F122-SP & 0.07 & 0.31 & 0.43 & 0.003 & 0.003 & 10.49 & 1.49 & 1.45 & 0.30 & 0.05 & 0.20 & - & 1.04 & - & - & Bal. \\
\hline ASME & BM & P92-IP & 0.12 & 0.02 & 0.47 & 0.0011 & 0.006 & 9.07 & 1.79 & - & 0.46 & 0.063 & 0.19 & 0.043 & 0.06 & 0.0028 & - & Bal. \\
\hline P92 & FM & P92-IP & 0.06 & 0.20 & 1.04 & 0.008 & 0.007 & 8.90 & 1.65 & - & 0.50 & 0.040 & 0.09 & 0.033 & 0.40 & - & - & Bal. \\
\hline
\end{tabular}

IP: for internal pressure creep test, P: for creep test of single pass welded joint, FM: filler metal

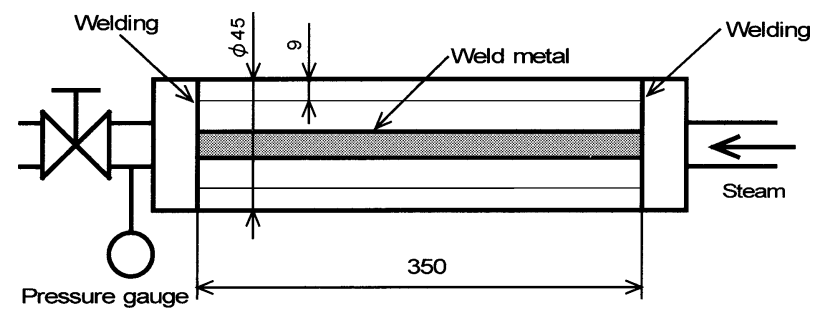

Fig. 1. Schematic diagram of internal pressure creep test for ASME P92 (mm).

Table 2. Welding condition for internal pressure creep specimen.

\begin{tabular}{|c|c|c|}
\hline \multicolumn{2}{|c|}{ Welding method } & Pulsed TIG \\
\hline \multicolumn{2}{|c|}{ Preheating temperature (K) } & 433 \\
\hline \multicolumn{2}{|c|}{ Number of weld passes } & 15 \\
\hline \multirow{2}{*}{$\begin{array}{c}\text { Welding current } \\
\text { (A) }\end{array}$} & Base & $120 \sim 140$ \\
\cline { 2 - 3 } & Peak & $180 \sim 210$ \\
\hline \multicolumn{2}{|c|}{ Arc voltage $(\mathrm{V})$} & 9.5 \\
\hline \multicolumn{2}{|c|}{ Welding speed $(\mathrm{mm} / \mathrm{s})$} & 1.5 \\
\hline \multicolumn{2}{|c|}{ Post weld heat treatment } & $1018 \mathrm{~K} \times 4.5 \mathrm{~h}$ \\
\hline
\end{tabular}

P122 and ASME P92 were tempered martensite.

\subsection{Internal Pressure Creep Tests}

Internal pressure creep tests were used to investigate the effect of applied stress on creep crack in welded joints. Figure 1 shows dimensions of creep test specimen for ASME P92. The tube was machined for the $U$ groove and was welded by pulse TIG in 15 passes, then post weld heat treatment (PWHT) was conducted at $1018 \mathrm{~K}$ for $4.5 \mathrm{~h}$. Table 2 shows the welding condition for the internal pressure creep specimen. Internal pressure creep tests were performed at $923 \mathrm{~K}$. Apparent stress in the wall of the tubes was controlled to be 108, 137, 167 MPa for ASME P122 specimens and 116, 137, $167 \mathrm{MPa}$ for ASME P92 specimens by changing steam pressure according to the following equation.

$$
\sigma=P\left(\frac{D}{2 t}-0.5\right)
$$

Where $\sigma$ is apparent stress in the middle of wall, $P$ is steam pressure, $D$ is outer diameter and $t$ is wall thickness. Since internal pressure creep specimens were welded by multi-pass weld, it was difficult to investigate the accurate relationship between welding thermal cycle and creep property degradation in the HAZ using only this test. Therefore single pass welded joint creep tests were carried out.

\subsection{Single Pass Welded Joint Creep Tests}

Figure 2 shows dimensions of single pass welded creep specimen. Firstly, a $U$ groove was machined on the outer

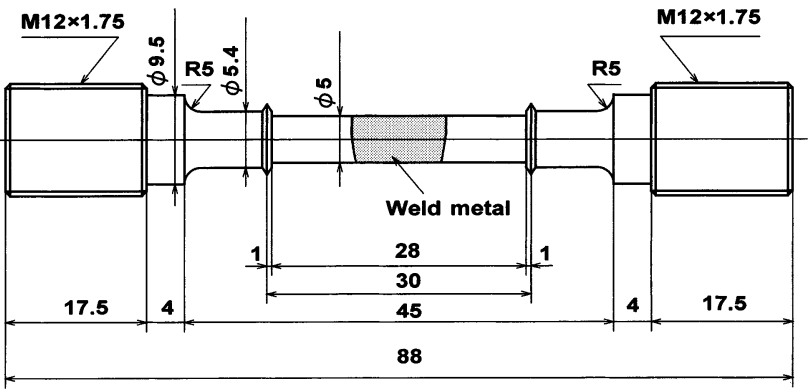

Fig. 2. Dimensions of single pass welded creep specimen (mm).

Table 3. Welding condition for single pass welded joint.

\begin{tabular}{|c|c|}
\hline Welding method & Hot wire TIG \\
\hline Preheating temperature $(\mathrm{K})$ & 423 \\
\hline Base welding current $(\mathrm{A})$ & 295 \\
\hline Arc voltage $(\mathrm{V})$ & 15 \\
\hline Welding speed $(\mathrm{mm} / \mathrm{s})$ & 1.17 \\
\hline Post weld heat treatment & $1018 \mathrm{~K} \times 4.5 \mathrm{~h}$ \\
\hline
\end{tabular}

surface of an ASME P122 tube of diameter $350 \mathrm{~mm}$ and thickness $53 \mathrm{~mm}$. A filler wire was fed by hot wire TIG and welding was performed with single pass to obtain a simple welding thermal cycle, which was measured during welding. Table 3 shows the welding condition for the single pass welded creep specimen. After weld, the tube was heated to $1018 \mathrm{~K}$ and kept for $4.5 \mathrm{~h}$ as PWHT. Finally, a series of specimens were cut from the tube and machined to single pass weld specimens. The creep tests were carried out at temperature of $923 \mathrm{~K}$ and applied stresses of 90 and 120 MPa. The creep tests of several specimens were interrupted at desired times but the other specimens were crept till fracture.

The reduction of area of the single pass welded specimen was measured by laser scanning micrometer. The analysis of creep void distribution was based on the microstructural observation. Elements of precipitates in creep voids were analyzed by AES.

\section{Experimental Results}

\subsection{Determination of Type IV Cracking}

Applied stresses of internal pressure specimens of ASME P92 were 116, 137 and $167 \mathrm{MPa}$ and their rupture times were $1188.2,561.7$ and $68.5 \mathrm{~h}$ respectively. Figures 3(a) and 3(b) show ASME P92 specimens ruptured at 167 and $116 \mathrm{MPa}$. It can be found that the specimen ruptured at $167 \mathrm{MPa}$ exhibited typical ductile failure with large diameter expansion and a crack in which the mouth largely opened. However, the specimen fractured at $116 \mathrm{MPa}$ exhibited typical brittle failure with small deformation. At 
low applied stress the crack occurred in the FGHAZ and was identified as Type IV cracking, but at high stress the crack occurred in the base metal and was identified as normal creep crack.

Internal pressure creep tests could not clarify the accurate relationship between welding thermal cycle and degradation of creep property in HAZ. Therefore, single pass welded specimen creep tests were performed. Figure 4 shows the specimen ruptured at $90 \mathrm{MPa}$ after $2763.2 \mathrm{~h}$. It was found that the crack occurred in the FGHAZ and the fractured surface was smooth and parallel to the weld fusion line. This creep fracture could be clearly identified as Type IV cracking.

Figure 5 shows the change of specimen diameter along

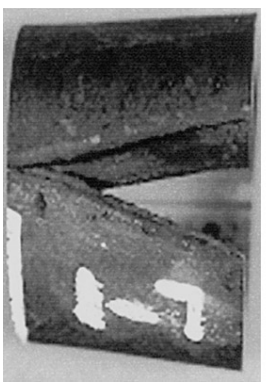

(a)

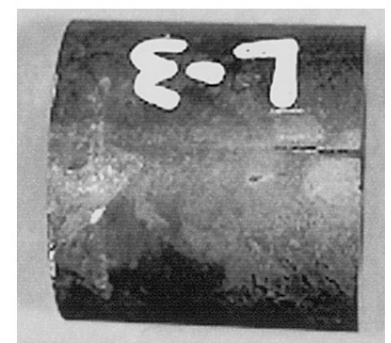

(b)
Fig. 3. Ruptured specimens of internal pressure test of ASME P92 at $923 \mathrm{~K}$

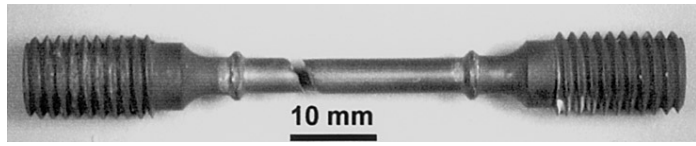

Fig. 4. Ruptured single pass welded specimen of ASME P122 (923 K, $90 \mathrm{MPa}$, tr: $2763.2 \mathrm{~h})$.

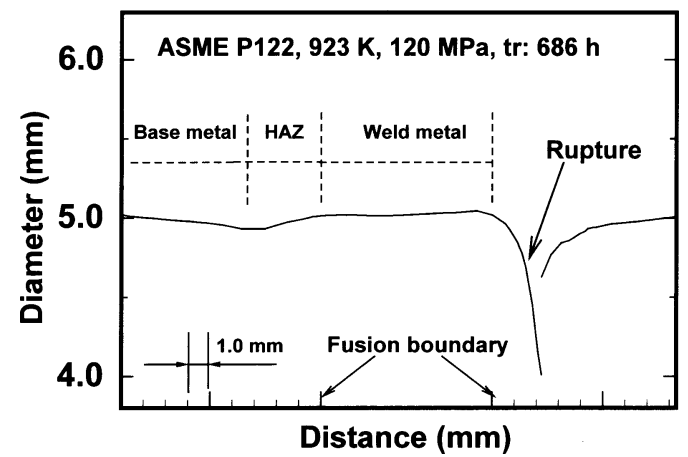

Fig. 5. Reduction in specimen diameter along longitudinal direction. longitudinal direction. It was noticed that the diameter in the HAZ was slightly small compared to the diameter of the base metal and weld metal, indicating that the reduction of area was larger in the HAZ. A careful observation showed that the position in which the diameter was smallest corresponded to the FGHAZ.

\subsection{Observation of Type IV Cracking}

\subsubsection{Creep Void Distribution}

The specimen of the single pass welded joint of ASME P122 was observed using an optical microscope. Figure 6 shows the microstructure of the weldment. It can be seen that in the HAZ region whose distance was more than 1.5 $\mathrm{mm}$ away from the fusion boundary, many voids occurred and some of them coalesced, and micro fissures began to form. This region belonged to FGHAZ. However, few creep voids occurred in the HAZ region near the fusion boundary, which belonged to CGHAZ.

\subsubsection{Comparison between Void Distribution and Peak Weld Temperature}

Creep void distribution and peak weld temperature in the welded joint were measured as a function of the distance away from the fusion boundary and the results are shown in Fig. 7. According to the result reported by J. Hald, ${ }^{14)}$ the equilibrium temperatures of $\mathrm{Ac}_{1}$ and $\mathrm{Ac}_{3}$ of $\mathrm{ASME} \mathrm{P} 122$ were 1078 and $1177 \mathrm{~K}$ respectively. However, the heating rate during welding is so fast that its effect should be taken into account. It was considered that the real temperature of $\alpha \rightarrow \gamma$ transformation was about $80-140 \mathrm{~K}$ higher than that of equilibrium transformation due to the high heating rate in welding. The microstructure of single pass welded joint specimen was carefully observed using an optical micro-

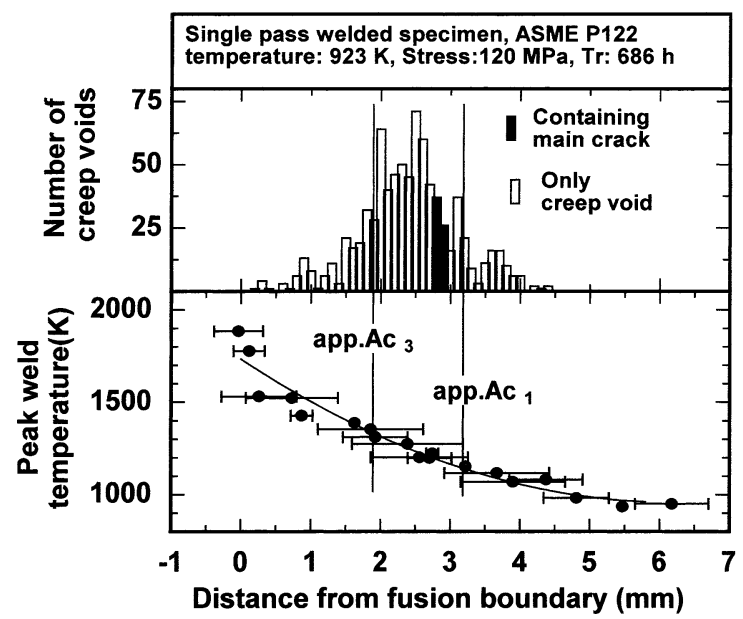

Fig. 7. Distribution comparison between creep voids and peak weld temperature.

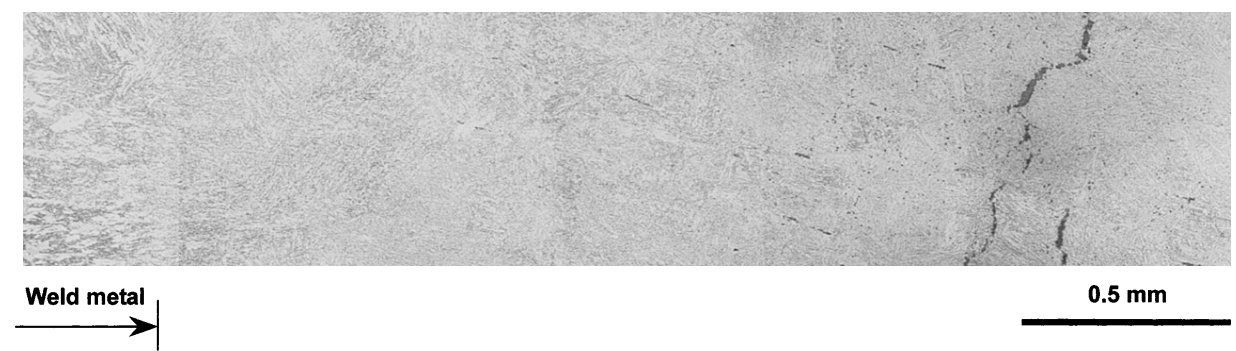

Fig. 6. Microstructure of single pass welded joint. 
scope. According to the observation from the base metal to the HAZ continuously, the microstructure change was found in the region in which $\alpha \rightarrow \gamma$ transformation began to appear. This region was regarded as the apparent $\mathrm{Ac}_{1}$ (app. $\left.A c_{1}\right)$. On the other hand, when the same observation from the CGHAZ to base metal was done, the grain size decreased and a region whose grain boundaries were difficult to distinguish was found. This region was regarded as the apparent $\mathrm{Ac}_{3}$ (app. $\mathrm{Ac}_{3}$ ). Based on the microstructure observation and peak weld temperature distribution, the transformation temperatures of $\mathrm{Ac}_{1}$ and $\mathrm{Ac}_{3}$ during the welding were determined to be about app. $\mathrm{Ac}_{1}(1160 \mathrm{~K})$ and app. $\mathrm{Ac}_{1}(1320 \mathrm{~K})$. The region of peak weld temperature between app. $A c_{1}$ and app. $A c_{3}$ is intercritical zone and is simply regarded as a part of FGHAZ in this study.

From Fig. 7, it can be seen that the largest number of creep voids occurred in the region of peak weld temperature between app. $\mathrm{Ac}_{1}$ and app. $\mathrm{Ac}_{3}$. The fracture position of the specimens was $2.8-2.9 \mathrm{~mm}$ away from the fusion boundary and was just located in this region. It is also obvious that the region of peak temperature between app. $\mathrm{Ac}_{1}$ and app. $\mathrm{Ac}_{3}$ showed the maximum degradation of material property during creep and finally led to Type IV cracking.

\subsection{Dependence of Creep Deterioration on Creep Time}

\subsubsection{Diameter Reduction during Creep}

As shown in Fig. 5, the diameter of the FGHAZ in the single pass welded creep specimen was small compared to the other regions. The creep tests of two specimens were interrupted after 200 and $308.2 \mathrm{~h}$ and the other two specimens were crept until creep fracture. For a ruptured specimen, there are two HAZs on the both sides of the WM but the creep fracture occurred in one of the HAZs. The diameter change in the HAZ without creep fracture was analyzed. Figure 8 shows the maximum diameter reduction as a function of creep time for the specimens. It can be found that the reduction in diameter increased with creep time and it seems to be accelerated after a creep time of about $300 \mathrm{~h}$.

\subsubsection{Creep Void Distribution during Creep}

Figure 9 shows creep void distributions in the side without fracture for all specimens. It can be seen that for the specimens crept for 200 and 308.2 h (Figs. 9(a) and 9(b)), few creep voids occurred and there was no apparent peak number of creep voids. After creep testing for 407.1 and $686 \mathrm{~h}$, many creep voids occurred in the region of peak

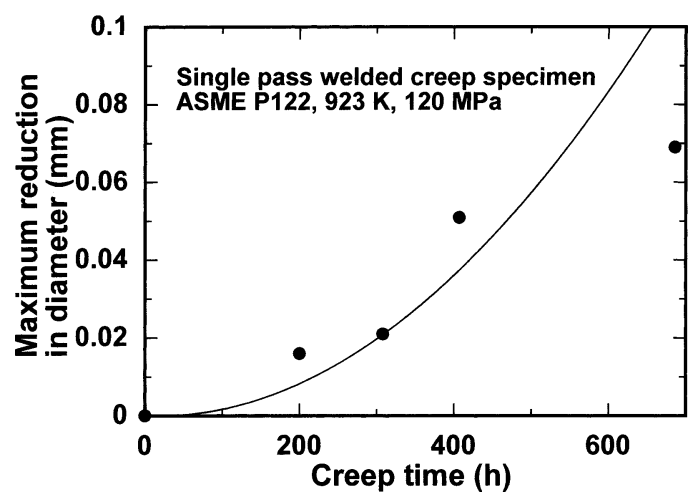

Fig. 8. The maximum reduction in diameter during the creep. weld temperature between app. $\mathrm{Ac}_{1}$ and app. $\mathrm{Ac}_{3}$, but the increase of void number in the base metal and CGHAZ was not obvious (Figs. 9(c) and 9(d)). It is apparent that the time from 308.2 to $688 \mathrm{~h}$ was the important stage for creep void occurrence in the FGHAZ.

\subsubsection{Precipitation Behaviour during Creep}

Figure 10 shows the quantitative analysis of the number

(a)

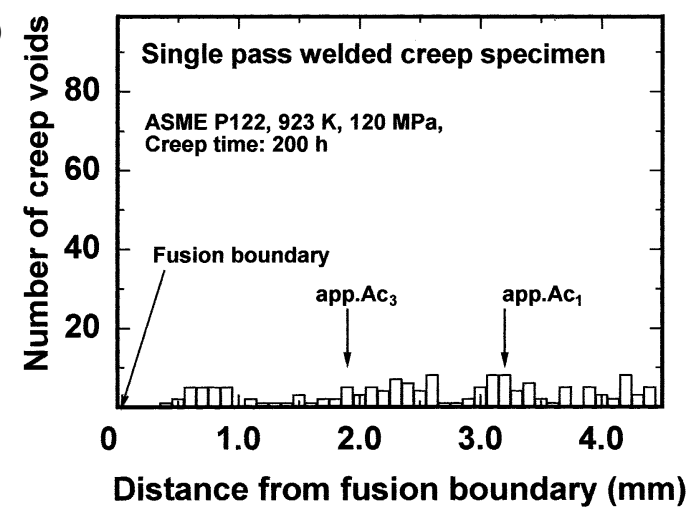

(b)

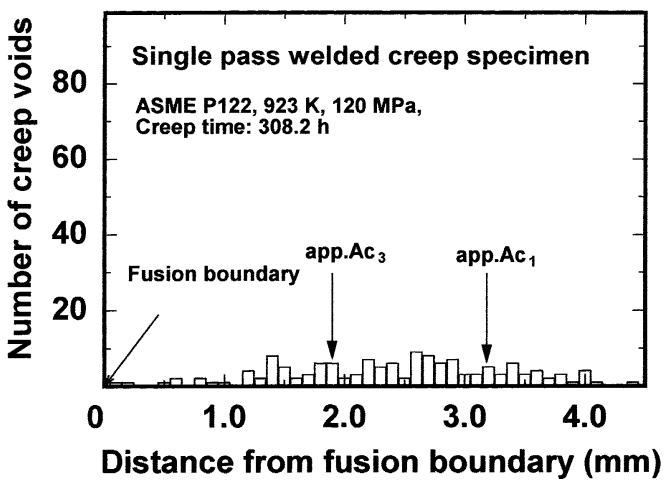

(c)

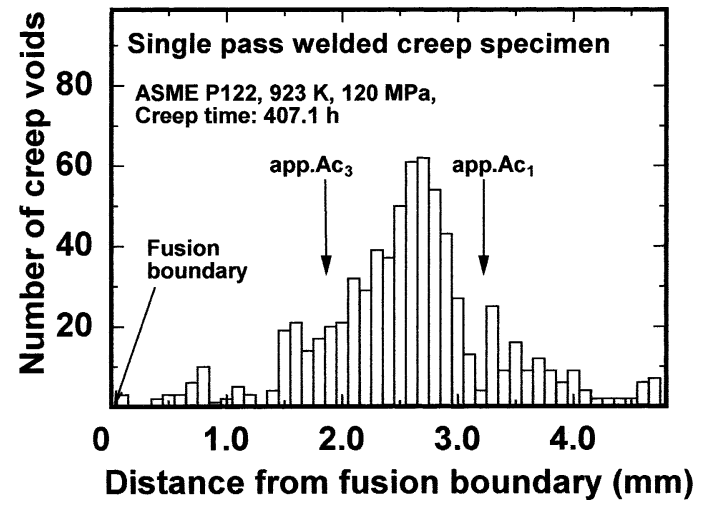

(d)

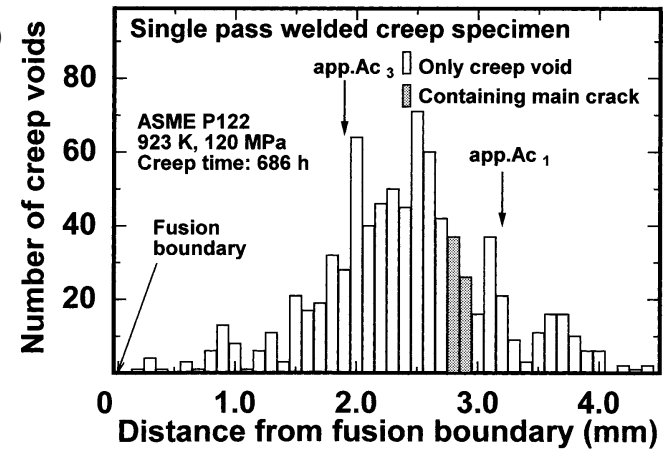

Fig. 9. Creep void distributions after different creep times at $923 \mathrm{~K}$ and $120 \mathrm{MPa}$ for ASME P122. 
and area fraction of precipitates in creep void region and in base metal during creep. It can be seen that after welding the area fraction of precipitates was lower in the creep void region than in the base metal, but the number of precipitates was almost the same for both regions. Further, for these two regions, the area fraction of precipitates increased with creep time due to coarsening but the number of precipitates decreased. It can be seen that after $686 \mathrm{~h}$ the creep void region had the much lower precipitate number but the same precipitate area fraction than the base metal. This phenomenon indicated that the coarsening process of precipitates was more in the creep void region than in the base metal. Based on this result, it can be considered that the

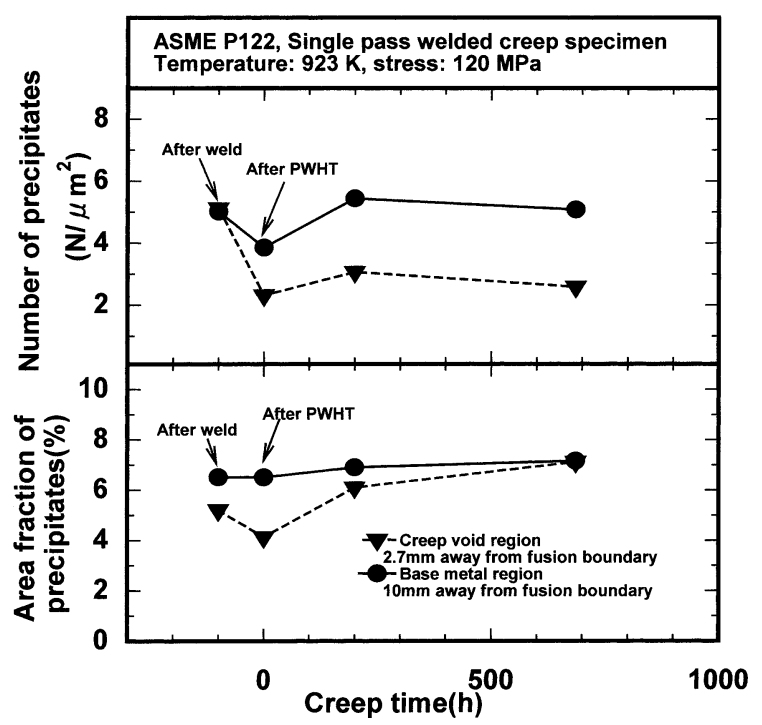

Fig. 10. Area fraction and number of precipitates as a function of creep time.

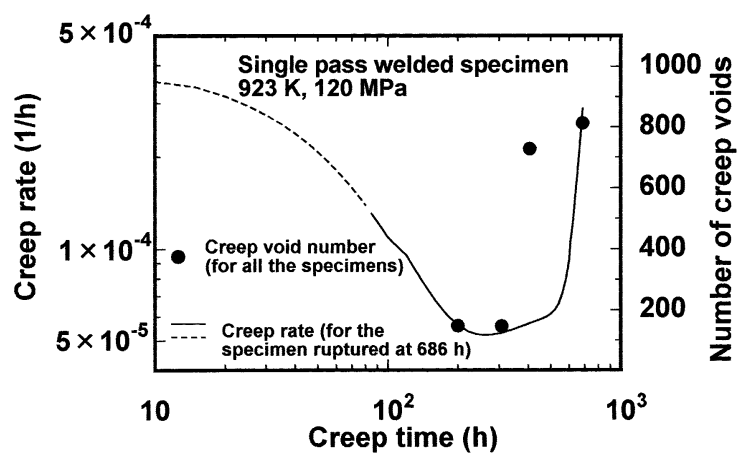

Fig. 11. Comparison between creep void occurrence and creep stages.

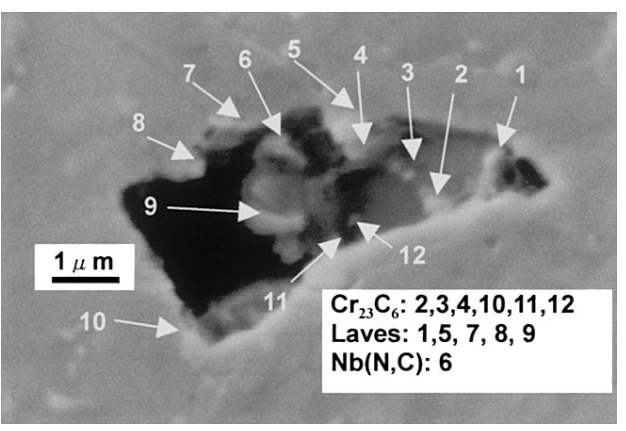

coarsening of precipitates in HAZ is an important factor that leads to the degradation of creep strength in HAZ.

\section{Discussion}

\subsection{Two Factors Affecting Creep Void Occurrence}

4.1.1. Relationship between Creep Stage and Void Occurrence

Figure 11 shows the variation of creep rate and number of creep voids with testing time. It should be noted that the variation of creep rate in this figure is for the specimen ruptured after $686 \mathrm{~h}$ but the number of creep voids is for all the specimens. The creep process of the specimen ruptured after $686 \mathrm{~h}$ can be apparently divided into three stages, the primary stage of decelerating strain rate from 0 to $200 \mathrm{~h}$, the secondary stage of steady strain rate from 200 to $500 \mathrm{~h}$, and the tertiary stage of accelerating deformation from 500 to $686 \mathrm{~h}$. Further, it can be seen the number of creep voids was low for the specimens interrupted at 200 and $308.2 \mathrm{~h}$ but high for the specimens ruptured at 407.1 and $686 \mathrm{~h}$, the creep void occurrence exhibited an accelerating rate during the creep. Many creep voids occurred in secondary and tertiary stages but few voids occurred in primary creep stage. However, it should be noted that it is difficult to accurately distinguish the difference of void number for secondary stage and tertiary stage because the creep curves of these specimens were different. Since creep voids can represent the extent of micro damage, it is apparent that the creep damage increased at an accelerating rate during creep.

\subsubsection{Relationship between Precipitate and Ccreep Void}

The precipitates in specimens were identified as Laves phase $\left(\mathrm{Fe}_{2} \mathrm{~W}\right), \mathrm{M}_{23} \mathrm{C}_{6}, \mathrm{MX}$ and so on based on the X-ray analysis for extraction residue of specimens. Figure 12 shows AES analysis for precipitates in a creep void of the single pass welded specimen fractured at $120 \mathrm{MPa}$ after $686 \mathrm{~h}$. It was found that the protruding points of void were precipitates and most of them seemed to be $\mathrm{M}_{23} \mathrm{C}_{6}$ and Laves. The result strongly suggested that precipitates were the nucleation sites of creep voids.

The observation of creep specimen showed that coarsened precipitates in the FGHAZ played an important role in Type IV cracking. Normally coarsened precipitates can cause creep property deterioration by decreasing the effects of solid solution strengthening and precipitation strengthening. In addition, the phenomenon that many large precipitates were observed inside creep voids implied that the precipitates also played an important role as nucleation sites of

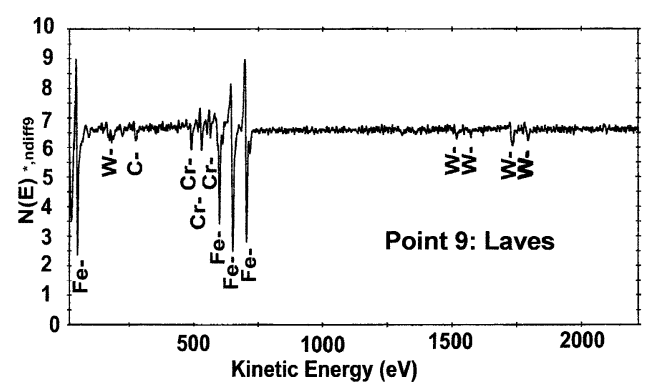

Fig. 12. AES point analysis of precipitates in void for the single pass welded specimen ruptured at $120 \mathrm{MPa}$ after $686 \mathrm{~h}$. 


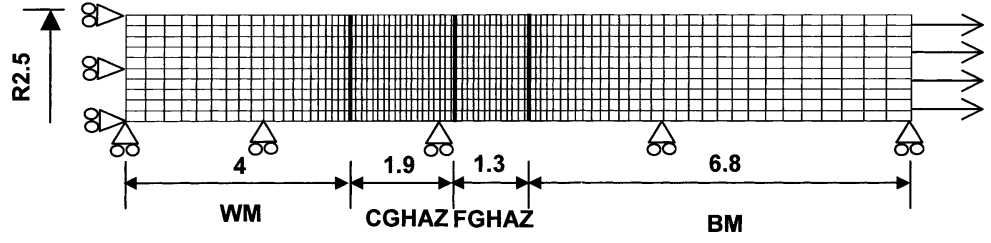

Fig. 13. Axisymmetric model of creep test of single pass welded joint (mm).
Table 4. Material properties used in simulation.

\begin{tabular}{|c|c|c|c|c|c|}
\hline \multirow{2}{*}{$\begin{array}{c}\text { ASME } \\
\text { P122 } \\
(923 \mathrm{~K})\end{array}$} & $\begin{array}{c}\text { Creep properties } \\
\left(\begin{array}{c}\mathrm{A} \\
\left(\mathrm{MPa}^{-\mathrm{n}} \mathrm{h}^{-1}\right)\end{array}\right.\end{array}$ & $\mathrm{N}$ & $\begin{array}{c}\text { Young's } \\
\text { modulus } \\
(\mathrm{GPa})\end{array}$ & $\begin{array}{c}\text { Yield } \\
\text { stress } \\
(\mathrm{MPa})\end{array}$ & $\begin{array}{c}\text { Poisson } \\
\text { ratio }\end{array}$ \\
\hline WM & $3.37 \times 10^{-57}$ & 24.0 & 106 & 91 & 0.3 \\
\hline CGHAZ & $6.97 \times 10^{-26}$ & 10.2 & 99 & 135 & 0.3 \\
\hline FGHAZ & $2.80 \times 10^{-24}$ & 9.8 & 77 & 82 & 0.3 \\
\hline BM & $3.76 \times 10^{-33}$ & 13.6 & 103 & 104 & 0.3 \\
\hline
\end{tabular}

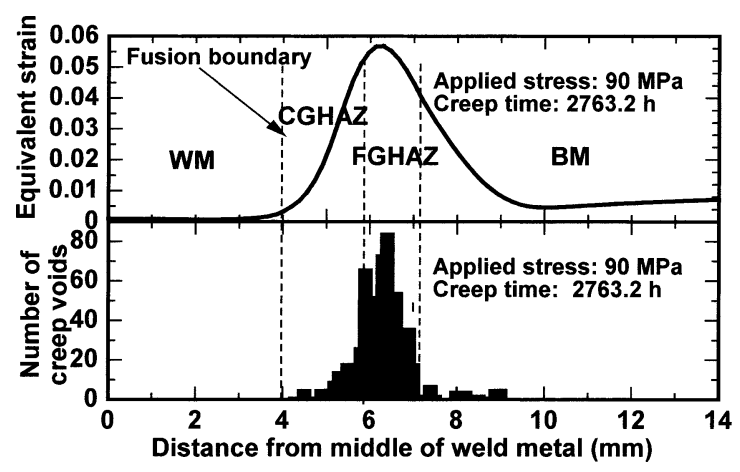

Fig. 14. Distribution comparison between equivalent strain and creep voids along length.

the creep voids.

Goods et al. ${ }^{15)}$ have found that cavities are usually associated with inclusions or second phase particles. A cavity can be induced by particle fracture or by separation of the particle/matrix interface. This behavior was commonly observed in both ferrous and non-ferrous systems. Many of the observations of homogeneous and grain boundary nucleation can be explained by the presence of small, unresolved particles. However, the mechanism of role of precipitate as nucleation site of void is complex. Since hard particle has large influence on the cavity nucleation, it can be thought that if cavity nucleation could be delayed or suppressed, the creep lifetime of structure can be expected to become longer. Therefore it is important for the design of high $\mathrm{Cr}$ ferritic steel to investigate the role of large precipitate as nucleation site of creep void.

\subsection{Simulation about Void Occurrence in Welded Joint}

In order to investigate the occurrence of creep voids in the single pass welded joint from strain/stress viewpoint, the simulation of single pass welded joint was performed. Figure 13 shows the FE model of creep test of single pass welded joint and Table 4 shows material properties used in the simulation. These parameters were measured by creep tests and tensile tests of the weld metal, base metal and synthetic HAZs whose thermal cycle corresponded to those in FGHAZ and CGHAZ. ${ }^{16)}$

Figure 14 shows a comparison between distributions of equivalent strain and creep void number along specimen at $90 \mathrm{MPa}$ after $2763.2 \mathrm{~h}$. It can be seen that equivalent strain and creep voids have almost the same distribution. The peak number of creep voids and the largest equivalent strain are located in the same position in the FGHAZ. This result shows that the equivalent strain can represent the extent of creep void occurrence in the creep test of single pass welded joint. Based on this viewpoint, it can be considered that the equivalent strain can be used to predict the occurrence of creep voids.

\subsection{Simulation of Effect of Precipitate on Void Oc- currence}

In order to investigate the role of precipitate in the initiation of creep void, FEM simulation of a micro model was performed. This model assumed that the hard precipitate was embedded in a matrix. The matrix represented the FGHAZ, CGHAZ or base metal. The matrix crept but precipitate didn't. The radius of spherical precipitate was assumed to be $0.2 \mu \mathrm{m}$ and matrix size was $4 \times 4 \times 4 \mu \mathrm{m}$. The Poison's ratio and Young's modulus of precipitate were assumed to be 0.22 and $600 \mathrm{GPa}$. Further, in order to investigate the effect of stress condition in the welded joint on the micro model, the stress results calculated by the welded joint model of Fig. 13 was introduced in this model. It should be pointed out that this is a simple model based on macro material properties and doesn't include many complex factors, such as diffusion, grain boundary, the material property of interface and so on.

When the applied stress was $100 \mathrm{MPa}$, the stress distribution in welded joint was calculated and the 3-D stress in the mesh with largest equivalent strain was chosen and introduced into the precipitate-matrix model as an applied stress. The stress condition varied with creep time. Figure 15 shows the contour map of equivalent strain field of precipitate-matrix model after $600 \mathrm{~h}$. The highest magnitude of equivalent strain occurs at the interface in matrix at angle about $45^{\circ}$ from the tensile loading direction. Therefore, this equivalent strain is used as a criterion of initiation of creep void in the following discussion.

Figure 16 shows the equivalent strains as a function of creep time with and without precipitate in the FGHAZ matrix. It can be seen that the equivalent strain with precipitate is more than twice of the condition without precipitate. This result indicates that precipitate facilitates void nucleation.

The material properties and stress condition are different for the regions of CGHAZ, FGHAZ and the base metal. Figure 17 shows the equivalent strain as a function of creep time when precipitate is located in the largest equivalent strain mesh in FGHAZ, CGHAZ and base metal respectively. It can be seen that FGHAZ has the highest strain concentration. In addition, it should be noted that the stress condition in weld joint model has large effect on matrix and precipitate model. If only material properties are taken into account and the applied stress is the same, FGHAZ will result in much higher equivalent strain at the interface than CGHAZ and base metal.

\section{Conclusions}

The causes of Type IV cracking in weldment of high $\mathrm{Cr}$ ferritic steel were investigated by creep tests and simulations. The following conclusions can be drawn: 


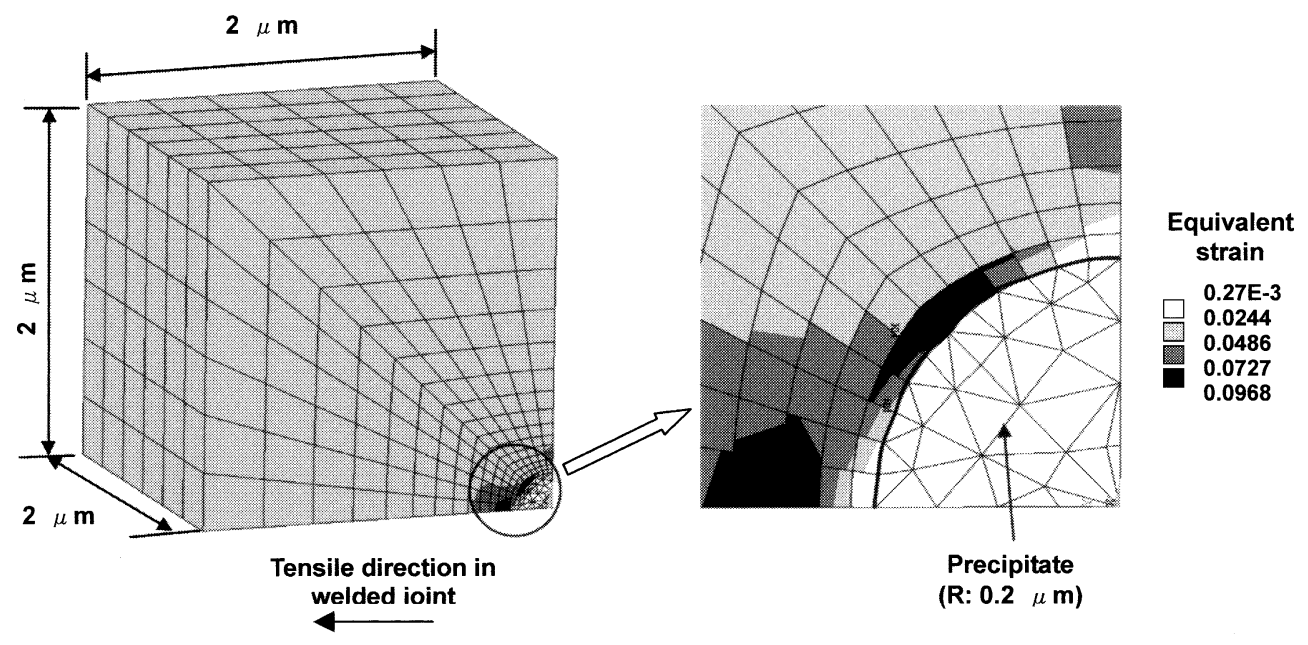

Fig. 15. Equivalent strain contour of precipitate and matrix after $600 \mathrm{~h}$ creep.

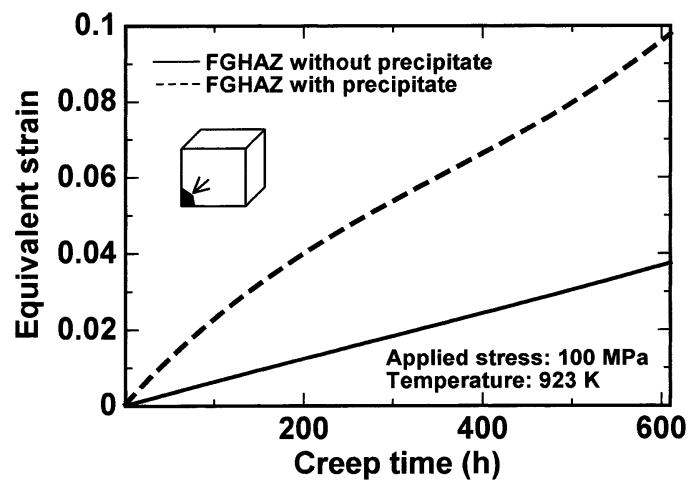

Fig. 16. Equivalent strains with and without precipitate as a function of creep time for FGHAZ matrix.

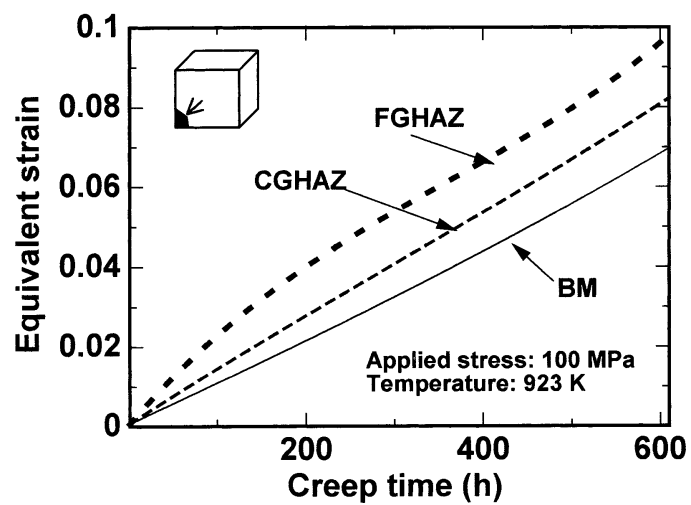

Fig. 17. Equivalent strains as a function of creep time when precipitate is located at the mesh with largest equivalent strain for FGHAZ, CGHAZ and BM.

(1) The degradation of creep strength in FGHAZ was considered to be induced by welding thermal cycle of peak weld temperature between app. $\mathrm{Ac}_{1}(1160 \mathrm{~K})$ and app. $\mathrm{Ac}_{3}$ $(1320 \mathrm{~K})$.

(2) The creep void number and specimen necking increased at an accelerating rate during creep. The largest void number and maximum necking occurred in the FGHAZ.

(3) AES point analysis showed that many precipitates existed in the creep voids. Coarsening of precipitates was more in creep void region than in base metal. It appeared that these large precipitates led to the deterioration of creep property in FGHAZ.

(4) The welded joint model showed that FGHAZ has the highest equivalent strain and largest deformation. There is a good agreement between distribution of equivalent strain and that of creep voids.

(5) The precipitate/matrix model showed that precipitate is easy to induce the initiation of creep void by acting as nucleation site in creep void occurrence. Creep void initiation is easy to occur in the FGHAZ compared with the CGHAZ and base metal.

\section{Acknowledgements}

The authors would like to express their sincere gratitude to Mr. T. Sato, Mr. K. Mitsuhata, and Mr. K. Tamura, in Babcook-Hitachi Co. Ltd., for their assistance in experiments, and Dr. M. Tabuchi, in National Institute for Metals Science, for the offering of material data of welded joint of high $\mathrm{Cr}$ ferritic heat-resisting steel.

\section{REFERENCES}

1) F. Masuyama: ISIJ Int., 41 (2001), 612.

2) H. Cerjak, P. Hofer and B. Schaffernak: ISIJ Int., 39 (1999), 874.

3) H. K. D. H. Bhadeshia: ISIJ Int., 41 (2001), 626.

4) Å. Gustafson and J. Ågren: ISIJ Int., 41 (2001), 356.

5) K. Kimura, K. Seiki, Y. Toda and F. Abe: ISIJ Int., 41 (2001), Suppl., S121.

6) K. Kougami and H. Isaka: Tetsu-to-Hagané, 76 (1990), 1043.

7) H. Kushima, K. Kimura, K. Yagi. and K. Maruyama: Tetsu-toHagané, 81 (1995), 214.

8) M. Matsui, M. Tabuchi, T. Watanabe, K. Kubo, J. Kinugawa and F. Abe: ISIJ Int., 41 (2001), Suppl., S126.

9) A. Iseda, Y. Sawaragi and K. Yoshikawa: Tetsu-to-Hagané, 77 (1991), 582.

10) H. Morimoto, S. Ohkita, H. Sakurai and M. Fui: Q. J. Jpn. Weld. Soc., 15 (1997), 664.

11) M. Igarashi, S. Muneki, H. Hasegawa, K. Yamada and F. Abe: ISIJ Int., 41 (2001), Suppl., S101.

12) T. Sourmail: Mater. Sci. Technol., 17 (2001), 1.

13) J. Mukhopadhyay, G. Piatti and A. Mukherjee: J. Mater. Sci., 25 (1990), 781.

14) J. Hald: The EPRI/National Power Conference, the Society of Chemical Industry, London, UK, (1995), 152.

15) S. H. Goods and L. M. Brown: Acta Mater., 27 (1979), 1.

16) M. Tabuchi, T. Watanabe, K. Kubo, M. Matsu, J. Kinugawa and F. Abe: J. Soc. Mater. Sci., Jpn., 50 (2001), 116. 